\author{
Agnieszka Chamera-Nowak \\ Katedra Książki i Historii Mediów \\ Wydział Dziennikarstwa, Informacji i Bibliologii \\ Uniwersytet Warszawski, Warszawa, Polska \\ achamera@uw.edu.pl \\ ORCID 0000-0001-6445-2143 \\ http://doi.org/10.33077/zbkh.2018.12.chamera
}

\title{
Biblioteki związków zawodowych w latach 50. XX wieku
}

\section{Abstract \\ Trade union libraries in the 1950 s of the $20^{\text {th }}$ century}

Trade union libraries were supervised by the Trade Unions' Central Council, defining areas of their activity, together with management boards of the unions of particular economic sectors. Regional councils of trade unions and management boards mentioned above were responsible for tasks' realisation. Direct supervision belonged to a trade union council and management of particular work places. Trade union libraries did not belong to the official library network. They fulfilled educational and community functions. Referring to the documents from the Archives of Modern Recordings, in 50s particular the acts of the Central Office for Publishing, Printing Industry and Bookselling, the Central Library Management, and the Central Committee of the Polish United Workers' Party, the author discussed briefly selected issues of the trade union libraries in the 50 s of the $20^{\text {th }}$ century.

Key words: libraries - trade unions - trade union libraries -1950 s of the $20^{\text {th }}$ century - Polish People's Republic.

Slowa kluczowe: biblioteki-związki zakładowe-biblioteki związkowe-lata 50. XX wieku-PRL.

Po II wojnie światowej biblioteki związków zawodowych ${ }^{1}$ powstawały zarówno przy wielkich zakładach przemysłowych takich jak huty, jak i przy

1 Tuż po wojnie związki zawodowe działały w oparciu o dekret z 8 II 1919 r. (Dz.U. z 1919 r., $\mathrm{Nr}$ 15, poz. 209), następnie na podstawie ustaw z 1 VII 1949 r. o związkach zawodowych (DZ.U. z 1949 r., Nr 41, poz. 293) oraz z 20 XII 1958 r. o samorządzie robotniczym (Dz.U. z 1958 r., $\mathrm{Nr} 77$, poz. 397). Reprezentacją ruchu zawodowego w Polsce w latach 1949-1980 było Zrzeszenie Związków Zawodowych (ZZZ), którego najwyższą władzą był Kongres Związków Zawodowych zwoływany co cztery lata, a w okresach między kongresami - Centralna Rada Związków Zawodowych (CRZZ). ZZZ posiadało struktury terenowe o zasięgu wojewódzkim i powiatowym (te nie funkcjonowały w latach 1953-1958 z powodu ich likwidacji przez CRZZ, a w latach 1975-1980 wskutek likwidacji powiatów). W skład ZZZ wchodziły poszczególne branżowe związki zawodowe (ponad 20), które kierowane były przez zarząd główny (następną instancją były zarządy 
małych rolniczych Państwowych Ośrodkach Maszynowych (POM) - te ostatnie były zwykle niewielkie. Zakładano biblioteki także w różnego rodzaju urzędach i instytucjach, np. biblioteki Związku Zawodowego Pracowników Państwowych obsługujące pracowników Gminnych (Gromadzkich) Rad Narodowych czy Związku Zawodowego Pracowników Handlowych (dla pracowników Gminnych Spółdzielni „Samopomoc Chłopska”). Nowo powstałe placówki działały w obrębie swoich zakładów pracy i nie tworzyły sieci bibliotecznych.

Historia bibliotek związków zawodowych wciąż czeka na opracowanie. Autorka podjęła jedynie próbę zasygnalizowania niektórych problemów funkcjonowania tych placówek w latach 50 . XX w. Szersze badania wymagają szczegółowych analiz dokumentów z akt związków zawodowych przechowywanych w Archiwum Akt Nowych (AAN) oraz w innych archiwach, m.in. dokumentacji Ogólnopolskiego Porozumienia Związków Zawodowych, a także materiałów przechowywanych w Bibliotece Uniwersytetu w Indianie w wydzielonej kolekcji nazwanej „Biblioteka Historii Ruchu Zawodowego” („History of the Workers’ Movement Library Collection”)2.

Informacje o bibliotekach związków zawodowych, ich sytuacji lokalowej, stanie księgozbiorów, zatrudnieniu personelu bibliotecznego oraz podejmowanych przez nie akcjach propagujących czytelnictwo pojawiają się w różnego rodzaju materiałach w formie maszynopisu lub rękopisu, znajdujących się w AAN aktach funkcjonującego w latach 1951-1956 Centralnego Urzędu Wydawnictw, Przemysłu Graficznego i Księgarstwa (CUWPGiK), w aktach utworzonego w 1951 r. Centralnego Zarządu Bibliotek (CZB), a także w dokumentach Komitetu Centralnego Polskiej Zjednoczonej Partii Robotniczej (KC PZPR). Pewnym uzupełnieniem materiałów źródłowych są późniejsze dokumenty i opracowania opublikowane m.in. w prasie branżowej, zwłaszcza raport z przeglądu wszystkich wykazywanych w statystykach bibliotek związkowych za 1973 r., który ujawnił m.in. fakt, że na

okręgowe i oddziałowe). Podstawową jednostką była zakładowa organizacja związkowa. Zob.: J. Naumiuk, Na poczatku trudnej drogi. Ruch zawodowy w Polsce Ludowej w latach 1944-1949, Łódź 1985; J. Chumiński, Ruch zawodowy w Polsce w warunkach ksztattujacego się systemu totalitarnego.1944-1956, Wrocław 1999; J. Jarosiński, Zwiazki zawodowe w teorii i praktyce partii rzadzacych w Polsce. 1944-1958, Kielce 2012; B. Rydz, Organizacja terenowych struktur zwiazków zawodowych w poludniowych powiatach województwa lubelskiego w latach 1944-1975, „Radzymiński Rocznik Humanistyczny” 2012, t. 10, s. 92-93.

2 Kolekcja zawiera wydawnictwa CRZZ działającej w PRL w latach 1949-1980: „647 wol. oprawnych gazet i czasopism, ok. 1550 numerów nieoprawionych periodyków oraz ok. 1250 wydawnictw monograficznych", cyt. za: Indiana University Bloomington Libraries - IUL, [The Polish collection at IUL; Polonica in the Libraries of Indiana University] (Biblioteki Uniwersytetu Stanu Indiana w Bloomington. Polska kolekcja) poz. 232. Ankieta 2012: Wookjin Cheun, [w:] Współczesne księgozbiory polskie za granica. Informator. 2: Polonika w bibliotekach obcych, oprac. B. Bieńkowska, E. Maruszak, J. Puchalski, Warszawa 2016, s. 542. 
ogólną liczbę 2637 placówek aż w 1152 nigdy nie przeprowadzono kontroli księgozbiorów ${ }^{3}$.

Biblioteki związków zawodowych funkcjonują w literaturze przedmiotu oraz w dokumentach archiwalnych, szczególnie w latach 50. XX w., pod różnymi nazwami jako: biblioteki związków zawodowych, biblioteki zakładowe, biblioteki oświatowe, biblioteki gromadzkie czy fachowe biblioteki zakładowe. Sytuacja ta wynika zapewne z kilku powodów. Przed II wojną światową używano nazw: biblioteki fabryczne, zakładowe, urzędowe czy techniczne dla bibliotek działających odpowiednio przy fabrykach, zakładach pracy, urzędach, większych instytucjach, stowarzyszeniach. Po wojnie biblioteki te zostały przekazane pod nadzór poszczególnych branżowych związków zawodowych ${ }^{4}$. Nowe placówki były zakładane przez związki zawodowe od 1944 r. i gromadziły początkowo nie tylko literaturę społeczno-polityczną i beletrystyczną, ale także fachową. Oprócz tego w dużych zakładach pracy działały inne biblioteki prowadzone np. przez organizacje społeczne czy techniczne, np. biblioteki klubów techniki i racjonalizacji (powiązane z Naczelną Organizacją Techniczną). Istniały jeszcze podręczne księgozbiory w poszczególnych oddziałach zakładów zawierające m.in. czasopisma fachowe. Taka sytuacja trwała przez wiele lat i nie sprzyjała rozwojowi tych placówek:

Potwierdza się powszechność zjawiska znanego z ankiet i wizytacji, że w tym samym zakładzie istnieją różne biblioteki i biblioteczki, pracujące na własną rękę w rozproszeniu wysiłków i niedostatecznymi środkami. [...] biblioteka świetlicowa, Klubów Techniki i Racjonalizatorstwa, NOT i techniczna ${ }^{5}$.

3 Raport omówił Zygfryd Rekosz w artykule Biblioteki związów zawodowych, „Bibliotekarz” 1976, nr 1-2, s. 26. Podał w nim liczbę 2597 bibliotek związkowych. Piotr Bierczyński zweryfikował tę liczbę na 2647, tj. 2555 bibliotek zakładowych, 41 międzyzakładowych, 17 central księgozbioru ruchomego, dziewięć bibliotek połączonych z placówkami innych sieci oraz 15 bibliotek w zakładowych ośrodkach wypoczynkowych, co nie jest prawdziwe, bo suma wyszczególnionych przez niego bibliotek daje liczbę 2637. Zob. P. Bierczyński, Biblioteki zakładowe. Stan obecny i perspektywy zmian, „Przegląd Biblioteczny” 1989, nr 2, s. 127.

4 Przykładem jest biblioteka Zakładów Żyrardowskich, która została założona w 1907 r. po masowych strajkach w latach 1905-1906. Ostatecznie otwarte zostały dwie biblioteki - fachowa dla kadry technicznej i urzędników oraz oświatowa dla robotników. Były to jedyne biblioteki w Żyrardowie aż do 1950 r., kiedy powstała Miejska Biblioteka Publiczna. Po II wojnie światowej bibliotekę fachową (Biblioteka Zrzeszenia Urzędników Zakładów Żyrardowskich) i oświatową (Biblioteka Robotnicza) połączono, a od 1946 r. nowa placówka podlegała Związkowi Zawodowemu Pracowników Przemysłu Włókienniczego. Początkowo, do 1949 r., oprócz finansowego wsparcia zakładów, biblioteka pobierała drobne opłaty od czytelników. W 1950 r. została przeorganizowana na wzór radzieckich bibliotek wzorcowych - wprowadzono nowe formy pracy bibliotecznej (m.in. nowy układ katalogowy) i łączności z czytelnikami (tzw. „księgonoszy”). Działała do 1983 r., kiedy to stała się filią MBP. Zob. m.in. M. Twardowski, Biblioteka Związkowa w Żyrardowie, [w:] Aktywność kulturalna włókniarzy. Praca zbiorowa, pod red. A. Kamińskiego i J. Marczaka, Łódź 1969, s. 103-104.

5 M. Mikołajski, O rozwój czytelnictwa w zakladach produkcyjnych, „Bibliotekarz” 1953, nr 5, s. 141-143. 
W szeregu dokumentów zawierających sprawozdania z wizytacji bibliotek, szczególnie na terenach wiejskich, ale także miejskich zakładów pracy, często znajdują się uwagi typu „do niedawna w gromadzie Konieczno pow. Włoszczowa w jednej sali były umieszczone biblioteka gminna, biblioteka ZMP oraz MO, a żadna nie pracowała"6.

Na początku lat 50. próbowano uporządkować sprawy bibliotek działających w zakładach pracy, tj. wydzielić w odrębną sieć placówki fachowe, w skład której miały wejść biblioteki klubów techniki i racjonalizacji, jak również księgozbiory podręczne z wyjątkiem literatury pięknej oraz księgozbiorów będących w gestii związków zawodowych i organizacji społecznych ${ }^{7}$. Jednak uchwała Prezydium Rządu z dnia 24 IX 1953 r. w sprawie rozwoju sieci fachowych bibliotek zakładowych, która nakazywała ścisłą współpracę z bibliotekami związków zawodowych i organizacji społecznych, mówiła także o umieszczaniu ich - w miarę możliwości - we wspólnym lokalu oraz obejmowaniu wspólną obsługą biblioteczną. Stąd zapewne pojawiające się w materiałach niejednoznaczne nazwy dla obu typów bibliotek, w tym „biblioteki zakładowe”. W przypadku placówek związków zawodowych nazwa „biblioteki zakładowe” upowszechniła się dopiero po 1981 r., kiedy poszczególne zakłady przejęły administrację bibliotek od związków zawodowych. Natomiast placówki, których organizatorem pozostały związki zawodowe, określane nadal były jako „biblioteki związkowe” lub „związkowe biblioteki zakładowe" ${ }^{8}$. Obecnie obowiązująca ustawa o bibliotekach rozróżnia placówki fachowe i zakładowe ${ }^{9}$. Pierwsze, jako wspierające realizację zadań zakładów pracy oraz służące potrzebom doskonalenia zawodowego pracowników, drugie - mające zaspokajać potrzeby oświatowe i kulturalne pracowników i ich rodzin. Na potrzeby niniejszego artykułu autorka będzie

6 AAN, KC PZPR, 237/VIII-13, Ocena analizy pracy bibliotek województwa kieleckiego [16.05.1953], s. 88-91.

7 Państwowa Komisja Planowania Gospodarczego (PKPG) w związku z pracami przygotowawczymi do planu sześcioletniego, wydała 29 IV 1949 r. pismo okólne w sprawie jednolitego zorganizowania prac bibliotek fachowych wraz z określeniem ich zadań. PKPG zaleciła wówczas zakładanie nowych i rozszerzanie istniejących placówek fachowych, ustaliła cele i wytyczne ich działalności. Na podstawie okólnika PKPG powstało wiele nowych bibliotek fachowych. W $1950 \mathrm{r}$. powstała pierwsza resortowa sieć bibliotek fachowych Ministerstwa Komunikacji. Uchwała nr 697 Prezydium Rządu z dnia 24 IX 1953 r. w sprawie rozwoju sieci fachowych bibliotek zakładowych (,Monitor Polski” 1953, nr A-94, poz. 1306) zobowiązywała zakłady pracy zatrudniające ponad 100 pracowników do zakładania i prowadzenia bibliotek fachowych, które powinny w ramach danego resortu utworzyć sieć. Zwolnione z tego obowiązku były zakłady, które mogły korzystać z innej biblioteki fachowej istniejącej w pobliżu i posiadającej odpowiednią literaturę fachową. Zob. J. Nowakówna, Organizacja i zasięg działania fachowych bibliotek zakładowych, [w:] Zagadnienia popularyzacji wiedzy i czytelnictwa, pod red. K. Wojciechowskiego, Wrocław 1966, s. 111.

8 P. Bierczyński, dz. cyt., s. 125.

9 Ustawa z dnia 27 czerwca 1997 r. o bibliotekach, Dz.U. 1997, Nr 85, poz. 539 z późn. zm. 
używać w odniesieniu do placówek związków zawodowych nazwy biblioteki związkowe lub biblioteki zakładowe.

Funkcjonowanie bibliotek związków zawodowych regulowały przepisy prawne ogólne oraz branżowe, jak np. chwała Sekretariatu CRZZ z dnia 10 I 1951 r., „Instrukcja o organizacji bibliotek i ochronie majątku książkowego w związkach zawodowych" CRZZ z 10 V 1955 r., zalecenia CRZZ z 10 I 1959 r. (nr 6/8/11/59) ${ }^{10}$, uchwała Prezydium Rządu nr 941/55 w sprawie zasad urządzania i finansowania placówek kulturalno-oświatowych w zakładach pracy oraz w sprawie płac pracowników kulturalno-oświatowych ${ }^{11}$. Przepisy te ustalały, że w skład związkowej sieci bibliotecznej ${ }^{12}$ wchodzą: biblioteki stałe, centrale księgozbioru ruchomego oraz punkty biblioteczne i księgozbiory podręczne zwane bibliotekami podręcznymi. Biblioteki stałe miały być organizowane w przedsiębiorstwach, instytucjach i zakładach pracy zatrudniających ponad 500 pracowników w mieście i ponad 300 na wsi. Oprócz tego miejskie punkty biblioteczne obsługiwać miały Centrale Księgozbioru Ruchomego $(\mathrm{CKR})^{13}$, przy czym warunkami ich funkcjonowania były: odpowiedni lokal wraz z wyposażeniem, księgozbiór liczący nie mniej niż 1000 tomów oraz fundusze na opłacanie bibliotekarza, uzupełnianie księgozbioru oraz zakup pomocy bibliotecznych. Uchwała nr 941/55 nakładała na administrację zakładów pracy obowiązek utrzymania biblioteki związkowej i jej pracowników ${ }^{14}$. Natomiast związki zawodowe miały opłacać zakup i oprawę książek, prenumeratę czasopism oraz organizację imprez i propagandę czytelnictwa. Niestety, przepisy te były dowolnie interpretowane zarówno przez związki zawodowe, jak i zakłady pracy. Brak realizacji uchwał CRZZ

10 Zbiór przepisów prawnych dla bibliotek związowych, wybór i oprac. Z. Rekosz, Warszawa 1977, s. 24-25, 29-39.

11 Uchwała nr 941 Prezydium Rządu z dnia 2 grudnia 1955 r. w sprawie zasad urządzania i finansowania placówek kulturalno-oświatowych w zakładach pracy oraz w sprawie płac pracowników kulturalno-oświatowych, „Monitor Polski” 1955, nr 127, poz. 1627.

12 Placówki te nie stanowiły jednak w rzeczywistości sieci bibliotecznej, choć w dokumentach używane jest to określenie. Sieć bibliotek związków zawodowych, w myśl przepisów bibliotecznych i ustawy o bibliotekach z 1968 r., rozpoczęto tworzyć dopiero w latach 70., co było reakcją Sekretariatu CRZZ na ustawę. W listopadzie 1973 r. CRZZ podjęła uchwałę o stosowaniu niektórych przepisów ustawy, a w kwietniu 1975 r. wydała instrukcję w sprawie zasad organizacji i prowadzenia związkowych bibliotek zakładowych. Jednak z chwilą likwidacji CRZZ w $1980 \mathrm{r}$. przepisy te stały się nieaktualne. Zob. Zbiór przepisów prawnych..., dz. cyt., s. 24-25, 29-39; P. Bierczyński, dz. cyt., s. 125.

13 Historia CKR-ów jest dość burzliwa, bowiem w ciągu kilkudziesięciu lat to rozwijały swoją działalność, to ulegały likwidacji, by ponownie zacząć funkcjonować. Zob. Z. Rekosz, dz. cyt., s. 20-21; P. Bierczyński, dz. cyt., s. 129.

14 Zgodnie z tabelą płac zamieszczoną w uchwale pracownicy kulturalno-oświatowi prowadzący biblioteki do 2000 tomów i obsługujący 300 czytelników otrzymywali za to dodatek w wysokości 60 zł miesięcznie. Uchwała nakazywała prowadzenie większych bibliotek przez samodzielnego bibliotekarza. Natomiast za prowadzenie punktu bibliotecznego nie przysługiwało wynagrodzenie. 
przez poszczególne instancje związkowe spowodowała, że ogromna większość zakładów pracy i częściowo hoteli robotniczych oraz Domów Młodego Robotnika (DMR) znajdowała się poza zasięgiem sieci bibliotecznej: np. w województwie wrocławskim na 114 hoteli w 40 brak było księgozbiorów, w województwie poznańskim na 38 hoteli i DMR - w 15, w województwie koszalińskim na 19 hoteli i DMR - w 16, do tego w województwie kieleckim większość punktów bibliotecznych była martwa, tj. nie wymieniono w nich książek przez ponad rok ${ }^{15}$. Wśród zakładów zatrudniających do 500 pracowników, tylko jedna trzecia posiadała punkty biblioteczne, ale najczęściej nie dysponowały one ani własnym lokalem, ani funduszami na zakup książek ${ }^{16}$.

Pierwsze powojenne ogólnopolskie dane odnoszące się do bibliotek związkowych pochodzą z 1954 r. ${ }^{17}$ „Rocznik Statystyczny” 1955 podaje, że było ich 4834, posiadały 6618300 tomów oraz obsługiwały 1049400 czytelników. Jednak dane te trudno uznać za miarodajne, bowiem brak było kryteriów określających placówkę związkową jako jednostkę sprawozdawczą. Do bibliotek tych kwalifikowano często punkty biblioteczne lub liczące kilkaset woluminów księgozbiory znajdujące się na przykład w hotelach robotniczych. Stąd liczba bibliotek w latach 1954-1979 podawana w kolejnych rocznikach statystycznych potrafiła maleć lub wzrastać od kilkunastu do ponad 1300 rocznie $^{18}$. Można domniemywać, że wynikało to z nieprawidłowej ewidencji, a także likwidacji czy też łączenia poszczególnych placówek z powodu reorganizacji. Pod koniec lat 50. pojawiły się w prasie doniesienia o likwidowaniu bibliotek przez niektóre zakłady pracy, co usprawiedliwiano szukaniem oszczędności - na przykład w 1957 r. zlikwidowano je w 140 łódzkich zakładach pracy ${ }^{19}$.

Wiele bibliotek i punktów bibliotecznych poszczególnych związków zawodowych nie wypełniało obowiązku sprawozdawczości, stąd trudno jest określić ich faktyczną liczbę - przykładowo pod koniec 1952 r., jak wynika z dokumentów archiwalnych CUPGiK, ,pełnego obrazu stanu wyposażenia w książkę i stanu czytelnictwa w powiecie [Wołomin - AChN] nie ma nikt" ${ }^{20}$, a w referacie bibliotek Wydziału Kultury Miejskiej Rady Narodowej

\footnotetext{
AAN, KC PZPR, 237/VIII-429, Analiza pracy bibliotek związków zawodowych, s. 5.

16 AAN, KC PZPR, 237/VIII-429, Notatka o bibliotekach związkowych i stanie czytelnictwa w zakładach pracy. Warszawa, marzec 1955, s. 39. Zob. też m.in. K. Kaźmierowska, M. Słobodzian, Biblioteki zwiazków zawodowych woj. poznańskiego w Polsce Ludowej, „Informator Bibliotekarza Wielkopolskiego" 1961, nr 1, s. 57.

„Rocznik Statystyczny” 1955, druk 1956, s. 256.

P. Bierczyński, dz. cyt., s. 126.

19 Zob. J. Kor. [Józef Korpała], Przeglad piśmiennictwa. Z zagadnień bibliotekarstwa i czytelnictwa w prasie, „Bibliotekarz” 1957, nr 7, s. 211-212; tenże, Przegląd piśmiennictwa ..., tamże 1957, nr 8, s. 248.

20 AAN, CUWPGiK, 65, Sprawozdanie z wyjazdu do Radzymina pow. Wołomin w celu zebrania danych stanu czytelnictwa - koniec listopada [1952], knlb.
} 
w Pułtusku zarejestrowano tylko cztery biblioteki związków zawodowych, choć faktycznie było ich więcej, ale „nie wiadomo dokładnie ile"21.

Naczelny nadzór nad placówkami związkowymi sprawowała, jak wspomniano, CRZZ, która wraz z zarządami głównymi poszczególnych związków branżowych wytyczała kierunki ich działania. Za realizację zadań odpowiedzialne były Wojewódzkie Rady Związków Zawodowych (WRZZ) oraz zarządy główne związków branżowych. Natomiast bezpośredni nadzór sprawowała rada zakładowa oraz kierownictwo zakładu pracy. Nadzór merytoryczny i opiekę fachową, zgodnie z porozumieniem zawartym w tej sprawie między Ministerstwem Kultury i Sztuki (MKiS) a CRZZ, przejęły od 1961 r. wojewódzkie biblioteki publiczne ${ }^{22}$. Zgodnie z tą strukturą biblioteki działające przy WRZZ w 1952 r. przekształciły się w wojewódzkie CKR, które obejmowały swoją działalnością punkty biblioteczne w zakładach pracy oraz były koordynatorami wszystkich bibliotek związkowych i innych CKR (przy zarządach okręgowych poszczególnych związków branżowych, np. pracowników przemysłu spożywczego, energetyki itd.) w danym województwie, prowadząc szkolenia i działalność instruktażowo-metodyczną dla kierowników punktów bibliotecznych w zakresie techniki bibliotecznej, pracy z książką i czytelnikiem. CKR posiadały zwykle dwóch pracowników etatowych, którzy nie byli w stanie wypełniać swoich zadań - „,na jednego pracownika CKR przypada od 30 (Kielce) do 100 punktów bibliotecznych (Stalinogród), w Związku Radzieckim na jednego instruktora CKR przypada 15 punktów"23. Niedobór i płynność kadr powodowała, że „W 5 skontrolowanych CKR obejmujących 740 punktów bibliotecznych ponad 60 proc. wymienia komplety raz na rok, niecałe 40 proc. raz na kwartał lub raz na pół roku"24. W 1956 r. CRZZ podjęła decyzję o likwidacji bibliotek w zakładach liczących do 500 pracowników i przekazaniu ich zasobów bibliotekom publicznym w zamian za nadzór merytoryczny nad większymi placówkami. Natomiast w grudniu tego roku MKiS wydał zarządzenie, które spowodowało likwidację wojewódzkich bibliotek związków zawodowych wraz z CKR. W styczniu 1957 r. nastąpiła likwidacja CKR-ów działających przy zarządach okręgowych związków branżowych, których księgozbiory przejęły biblioteki publiczne lub zostały one rozdzielone pomiędzy biblioteki stałe poszczególnych związków branżowych ${ }^{25}$.

Pod koniec 1954 r. czternaście komitetów wojewódzkich PZPR (bez białostockiego, gdańskiego i bydgoskiego) na zlecenie Wydziału Propagandy

21 AAN, CUWPGiK, 65, Sprawozdanie z wyjazdów odbytych w celu zebrania danych, dotyczących stanu upowszechnienia czytelnictwa i książki w pow. Pułtuskim [1952], knlb.

22 Z. Rekosz, dz. cyt. s. 169-171.

23 AAN, KC PZPR, 237/VIII-429, Notatka o bibliotekach..., s. 41.

24 Tamże.

25 K. Kazimierowska i M. Słobodzian, dz. cyt., s. 55-57. 
i Agitacji KC przeprowadziło analizę pracy bibliotek związków zawodowych, która objęła łącznie 3266 placówek stałych, 52 CKR prowadzące 5752 punkty biblioteczne ${ }^{26}$. Najwięcej bibliotek stałych było w Katowicach (600), Wrocławiu (447), Poznaniu (425) i Warszawie (368), a najmniej w Olsztynie (33). Najwięcej punktów bibliotecznych obsługiwały CKR we Wrocławiu (1527), Warszawie (834) i Łodzi (541), a najmniej w Kielcach (145), Zielonej Górze (189) i Lublinie (195). W wielu małych i średnich zakładach pracy istniały tzw. „karłowate” biblioteki, często całkowicie „wyczytane” (np. księgozbiór Centralnego Domu Towarowego liczył 522, a Zakładów im. Róży Luksemburg - 600 tomów). Wiele księgozbiorów obejmowało zaledwie od stu do dwustu książek, a nawet, jak w województwie warszawskim, poniżej stu. Na ogół w zakładach zatrudniających powyżej 2000 pracowników działały biblioteki stałe, wyjątkiem był np. Rejon Przemysłu Leśnego w Poznaniu.

Księgozbiory bibliotek związkowych kompletowane były bez skoordynowanego planu i pochodziły z trzech źródeł:

1. darów i pozostałości po bibliotekach prowadzonych przez różne stowarzyszenia i organizacje;

2. z akcji „Społeczna pomoc bibliotekom”, która w rzeczywistości sprowadziła się do upłynnienia remanentów Domu Książki (DK), w tym wielu niekompletnych tomów dzieł Włodzimierza Lenina i Józefa Stalina, licznych egzemplarzy książek jednego tytułu i broszur, które, jak wykazywały statystyki, były czytane w nikłym stopniu. Ponad 200000 takich książek otrzymał Związek Zawodowy Pracowników Rolnictwa (ZZPR), który nadzorował biblioteki w Państwowych Gospodarstwach Rolnych (PGR) i Państwowych Ośrodkach Maszynowych (POM) ${ }^{27}$;

3. zakupu - do $1954 \mathrm{r}$. prowadzony był on centralnie przez zarządy główne związków zawodowych, uniemożliwiając zaspokojenie rzeczywistych potrzeb czytelników, co miało wpływ na stan i poziom czytelnictwa.

Niejednokrotnie z punktów bibliotecznych i bibliotek w PGR-ach, POM-ach, czy spółdzielniach produkcyjnych korzystało zaledwie po kilka osób ${ }^{28}$. Dowodziły tego sprawozdania pokontrolne, jak to z powiatu płońskiego z 1954 r., w którym skonstatowano, że „na terenie PGR zagadnienie rozwoju czytelnictwa nie jest bliżej znane"29. Podział pieniędzy

\footnotetext{
26 AAN, KC PZPR, 237/VIII-429, Analiza pracy bibliotek..., s. 3-4.

27 AAN, CUWPGiK, 65, Dane dotyczące stanu sieci bibliotecznej na terenie Związku Zaw. Pracowników Rolnictwa. Struktura organizacyjna bibliotek [1952], knlb.

28 J. Podgóreczny, Szukamy nowych form zbliżenia ksiązki do czytelnika, „Bibliotekarz” 1955, nr 11, s. 340 .

29 AAN, MKiS, CZB, 32, Stan czytelnictwa w pow. płońskim, woj. Warszawskiego. Opracowanie 1954 r., knlb.
} 
na zakupy był mocno zróżnicowany. Na przykład Związek Zawodowy Pracowników Kultury z 45000 zł przeznaczonych na książki 30000 zł przekazał dla CKR, 15000 zł dla swoich bibliotek stałych, reszta nie otrzymała nic. Związek Zawodowy Metalowców uzależnił dotacje od wpływu ze składek: w Warszawie Fabryka Samochodów Osobowych na Żeraniu (FSO) otrzymała 3000 zł, Zakłady im. Róży Luksemburg - 9000, natomiast Zakład im. Nowotki nie dostał nic ${ }^{30}$. Wiele rad zakładowych, które zmuszone były do wykorzystania funduszy na zakup książek, realizował go pod koniec roku, bez uwzględnienia potrzeb czytelniczych. Na przykład rada zakładowa Wytwórni Chemicznej w Sarzynie w województwie rzeszowskim kupiła w 1954 r. po prostu całą półkę wydawnictw w księgarni DK, tak jak ją ustawiono w placówce ${ }^{31}$. Część rad zakładowych w ogóle nie wykorzystywała przyznanych funduszy lub przeznaczała je na inne cele, na przykład na inwestycje zakładowe czy stroje dla zespołu pieśni i tańca. Często zakup pozostawiano bibliotekarzom, którzy nie mając przygotowania fachowego, nie byli w stanie kompetentnie sprostać temu zadaniu. Przy wielu placówkach istniały formalnie rady biblioteczne, ale te także nie pomagały bibliotekarzom w zakupach nowości. W województwie warszawskim listę zakupów zatwierdzał instruktor kulturalno-oświatowy w zarządzie okręgu związków zawodowych, natomiast w województwie olsztyńskim kierownik biblioteki Wojewódzkiego Domu Kultury ${ }^{32}$.

W efekcie były to często księgozbiory przypadkowe, nieodpowiadające potrzebom czytelników. Budziły także wiele ideologicznych zastrzeżeń czynników partyjnych, jak np. biblioteka warszawskich Zakładów im. Karola Świerczewskiego posiadająca większą ilość dzieł Gieorgija Plechanowa, „których nikt nie czyta, a nie posiada Obywateli Brandysa, Władzy Konwickiego"33. Nie pomogła przeprowadzona w 1952 r. selekcja księgozbiorów według spisów obowiązujących wszystkie biblioteki oświatowe. Nadal wiele placówek związkowych było, zdaniem partyjnych kontrolerów, „zaśmieconych" niepoprawną politycznie literaturą.

Wyłaniająca się z różnego rodzaju sprawozdań i opracowań z lat 50. XX w. struktura tematyczna księgozbiorów bibliotek związkowych potwierdzała ich oświatowy charakter - na ogół $60 \%$ stanowiła klasyka polska i obca, $25 \%$ literatura społeczno-polityczna, $20 \%$ popularnonaukowa i techniczna oraz $10 \%$ książki dla dzieci i młodzieży ${ }^{34}$. Najczęściej wypożyczano książki beletrystyczne, społeczno-polityczne tylko na potrzeby szkoleń i referatów oraz

30 AAN, KC PZPR, 237/VIII-429, Notatka o bibliotekach..., s. 47.

31 F. Grabowski, Z książka do robotników, „Bibliotekarz” 1955, nr 11, s. 338.

32 AAN, KC PZPR, 237/VIII-429, Analiza pracy bibliotek..., s. 8-9.

33 Tamże, s. 6-7.

34 Tamże, s. 7; F. Grabowski, dz. cyt., s. 338. 
publikacje przyrodnicze i geograficzne na potrzeby uczniów. Do najpoczytniejszych autorów zaliczono: Bolesława Prusa, Józefa Ignacego Kraszewskiego, Elizę Orzeszkową, Henryka Sienkiewicza i Stefana Żeromskiego, a z autorów współczesnych Igora Newerlego, Kazimierza Brandysa, Juliana Stryjkowskiego, Leona Kruczkowskiego, Wandę Wasilewską, Polę Gojawiczyńską i Marię Dąbrowską. Z zagranicznych pisarzy m.in.: Ilię Erenburga, Michaiła Szołochowa, Wasilija N. Ażajewa, Borysa Polewoja, a także Annę Seghers, Louisa Aragona czy Jorge`a Amado ${ }^{35}$.

Według danych z dokumentów archiwalnych z 1954 r. z bibliotek związków zawodowych korzystało przeciętnie ok. 20\% osób pracujących zawodowo, ale już wtedy uważano, że dane te są wyolbrzymione i niedokładne, bowiem wiele bibliotek nie prowadziło ewidencji czytelników - na przykład w partyjnym opracowaniu „Analiza pracy bibliotek związków zawodowych” odnośnie jednego z zakładów pracy z województwa szczecińskiego stwierdzono, że na ogół procent czytelników wśród załogi kształtuje się od 2 do $60^{36}$. W rzeczywistości jednak było to od 3 do $5 \%$, a do tego niemal połowę czytelników stanowiła pracująca i ucząca się młodzież $\dot{z}^{37}$. W powiecie pułtuskim cztery biblioteki związków zawodowych miały ogółem 291 czytelników, a pięć bibliotek parafialnych i jedna prywatna $-467^{38}$.

Około $50 \%$ zbiorów było nieopracowanych, a w wielu bibliotekach prowadzono niedbałą i nieprawidłową ewidencję ${ }^{39}$. Przyczyną był brak wykwalifikowanych kadr, ale także stosunek dyrekcji zakładów do spraw bibliotecznych. Przykładowo dyrektorzy PGR-ów lekceważyli zarządzenie ogłoszone w biuletynie Ministerstwa PGR (funkcjonowało w latach 1951-1956) z maja 1951 r., w którym polecano im typowanie bibliotekarzy spośród pracowników biurowych oraz zabezpieczanie bibliotek ${ }^{40}$.

Wiele bibliotek i punktów bibliotecznych nie było uporządkowanych, księgi ewidencyjne prowadzono nieprawidłowo lub w ogóle ich nie było, nie prowadzono dokumentacji wpływu i wypożyczeń, książki nie były oznaczone i często pozostawały niezabezpieczone, przez co ulegały zniszczeniu lub ginęły. Brakowało osób odpowiedzialnych za księgozbiór, komplety książek wymieniano raz na rok lub rzadziej, księgozbiory były zdezaktualizowane, często zdekompletowane. Na przykład:

\footnotetext{
35 AAN, KC PZPR, 237/VIII-429, Analiza pracy bibliotek..., s. 17.

Tamże, s. 15.

AAN, KC PZPR, 237/VIII-429, Notatka o bibliotekach..., s. 54.

AAN, CUWPGiK, 65, knlb., Sprawozdanie z wyjazdów...

AAN, KC PZPR, 237/VIII-429, Notatka o bibliotekach..., s. 48.

40 Tamże; AAN, CUWPGiK, 380, Protokół oraz analiza stanu czytelnictwa w PGR i POM WRCK w Białymstoku z 14 września 1955 r., k. 251-260.
} 
- w PGR w gminie Świbie (powiat Gliwice) w styczniu 1954 r. książki przechowywano w szafie w świetlicy, a ich opiekuna - 16-letnią „autochtonkę”, wyznaczono dopiero po interwencji wizytatorów $\mathrm{CZB}^{41}$

- w gminie Mrozów (powiat Środa Śląska), ,biblioteki PGR istnieją tylko formalnie. Zagubione, nie prowadzona ewidencja, np. w Marszowicach komplet książek podjął kierownik spółdzielni produkcyjnej, ale nie potrafi powiedzieć co się z nimi stało" ${ }^{\text {". }}$.

Tab. 1. Wykształcenie ogólne pracowników etatowych bibliotek związków zawodowych w procentach (dane na 1 I 1954)

\begin{tabular}{|c|c|c|c|c|c|c|c|}
\hline Biblioteki & $\begin{array}{c}\text { Ogółem } \\
\text { w proc. }\end{array}$ & \multicolumn{2}{|c|}{$\begin{array}{c}\text { Wykształcenie } \\
\text { podstawowe }\end{array}$} & \multicolumn{2}{|c|}{$\begin{array}{c}\text { Wykształcenie } \\
\text { średnie }\end{array}$} & \multicolumn{2}{|c|}{$\begin{array}{c}\text { Wykształcenie } \\
\text { wyższe }\end{array}$} \\
\hline Ogółem & 100 & 36 & 6 & 30 & 23 & 4 & 1 \\
\hline pełne & niepełne & pełne & niepełne & nełne & niepełne \\
\hline Wojewódzkie & 100 & 8 & 0 & 40 & 4 & 40 & 8 \\
\hline \begin{tabular}{c} 
Powiatowe \\
\hline Miejskie \\
(duże)
\end{tabular} & 100 & 19 & 1 & 40 & 30 & 6 & 4 \\
\hline $\begin{array}{c}\text { Miejskie } \\
\text { (małe) }\end{array}$ & 100 & 35 & 6 & 24 & 31 & 2 & 2 \\
\hline \begin{tabular}{c} 
Gminne \\
\hline
\end{tabular} & 100 & 45 & 9 & 26 & 19 & 0 & 12 \\
\hline
\end{tabular}

Oprac. własne na podstawie AAN, KC PZPR, 237/VIII-429, Analiza pracy bibliotek związków zawodowych, s. 27-28.

Na sytuację bibliotek związków zawodowych miał niewątpliwie wpływ brak fachowego personelu bibliotecznego. Wprawdzie CKR prowadziły szkolenia, ale przy nieustannej płynności kadr przynosiło to niewielkie efekty, tym bardziej, że najczęściej bibliotekarzami byli pracownicy z wykształceniem podstawowym, czasem niepełnym podstawowym, bardzo rzadko ze średnim. Na przykład w województwie poznańskim na 125 bibliotekarzy etatowych i ryczałtowych: 103 posiadało wykształcenie podstawowe, 17 -średnie, jeden

${ }^{41}$ AAN, MKiS, CZB, 103, Monografia stanu bibliotek i czytelnictwa w gminie Świbie, pow. Gliwice 1954.

42 AAN, MKiS, CZB, 104, Monografia stanu bibliotek i czytelnictwa w gminie Mrozów, pow. Środa Śląska, woj. Wrocławskie, grudzień-marzec 1954. 
- wyższe; w olsztyńskim na 33 bibliotekarzy: 20 podstawowe, 12 - średnie, jeden - wyższe, w tym pięciu miało przeszkolenie biblioteczne ${ }^{43}$.

Dla wielu osób praca w bibliotece była dodatkowym, niechcianym obciążeniem. Tym bardziej, że za działalność w punkcie bibliotecznym nie przysługiwało wynagrodzenie. W większych zakładach pracy bibliotekarzami byli kierownicy świetlic, niekiedy na etatach.

Tab. 2. Zatrudnienie bibliotekarzy w bibliotekach związków zawodowych w 1954 r. w wybranych miastach wojewódzkich

\begin{tabular}{|c|c|c|c|c|c|}
\hline & Ogółem & etatowych & ryczałtowych & społecznych & $\begin{array}{c}\text { w tym } \\
\text { po kursach }\end{array}$ \\
\hline Warszawa & 348 & 68 & 47 & 233 & 45 \\
\hline Pozná́ & 425 & 31 & 94 & 300 & 36 \\
\hline Rzeszów & b.d. & 35 & 50 & b.d. & kilku \\
\hline Kraków & 262 & 51 & b.d. & b.d. & b.d. \\
\hline Lublin & 177 & 24 & b.d. & b.d. & 15 \\
\hline
\end{tabular}

Oprac. własne na podstawie AAN, KC PZPR 237/VIII-429, Analiza pracy bibliotek związków zawodowych, s. 12.

Szkolenie kadr odbywało się w Wojewódzkiej Szkole Kulturalno-Oświatowej w Krakowie, prowadzonej przez ZZZ, na trzymiesięcznych kursach, podczas których na zagadnienia bibliotekarskie przeznaczano zaledwie 25 godzin $^{44}$. Poza tym w wielu województwach organizowano jednodniowe seminaria dla etatowych i ryczałtowych bibliotekarzy, ale frekwencja na nich była niewielka i wynosiła $20-50 \%{ }^{45}$.

Rady zakładowe nie przywiązywały wagi do przygotowania fachowego osób wyznaczonych do prowadzenia bibliotek czy punktów bibliotecznych:

uważają, że bibliotekarzem może być każdy, np. w Zakładach Chemicznych Boruta w Zgierzu bibliotekę Domu Młodego Robotnika prowadzi sprzątaczka; w PGR Dobrojewo i Działyń, pow. Gniezno - 16 letnie dziewczynki ${ }^{46}$.

Zwracano za to uwagę na pochodzenie społeczne i przynależność partyjną bibliotekarzy związkowych - w województwie warszawskim na 115 bibliotekarzy etatowych i ryczałtowych 27 było członkami PZPR, 26 - Związku

\footnotetext{
43 AAN, KC PZPR, 237/VIII-429, Analiza pracy bibliotek..., s. 12.

44 Tamże.

45 Tamże, s. 14.

46 Tamże, s. 13.
} 
Młodzieży Polskiej (ZMP); w rzeszowskim na 85 - 20 było członkami PZPR, 25 ZMP; w poznańskim $76 \%$ bibliotekarzy społecznych to robotnicy ${ }^{47}$. Jednak zatrudnieni w bibliotekarstwie związkowym członkowie partii nie przejawiali znaczącej aktywności politycznej i stosunkowo słabo oddziaływali na zespół bibliotekarski. Były to najczęściej osoby powyżej 50. roku życia, bez średniego wykształcenia, ze słabym przygotowaniem zawodowym. W sumie bezpartyjni stanowili 56\% ogółu ${ }^{48}$.

Brak przygotowania fachowego był powodem mało zróżnicowanych form pracy z czytelnikiem oraz propagandy książki. Tylko niektóre biblioteki wykazywały w tym względzie takie zaangażowanie jak biblioteka przy Hucie im. Nowotki w Ostrowcu Świętokrzyskim, która organizowała konkursy czytelnicze, spotkania z literatami, dyskusje nad książkami, głośne czytanie, pogadanki przez radiowęzeł, przygotowywała gazetki ścienne, błyskawice i wystawki czy biblioteka Wojewódzkiego Domu Książki (WDK) w Kielcach, która organizowała wystawy metodyczne i prowadziła ćwiczenia praktyczne z nowymi kierownikami punktów biblioteczny $\mathrm{ch}^{49}$. W analizowanych materiałach źródłowych poza pojedynczymi przypadkami nie odnotowano współpracy bibliotek związków zawodowych z placówkami powszechnymi. Nie istniała właściwie pomoc wyższych instancji związkowych dla bibliotek i bywało, że nie orientowały się one w stanie podległych placówek - przykładem może być Wydział Kulturalno-Oświatowy WRZZ w Łodzi, który nie potrafił podać danych dotyczących liczby bibliotek ani informacji o stanie ich kadr oraz o księgozbiorach. Podobnie było w przypadku rad okręgowych. Często wysyłany do zakładu instruktor KO nie interesował się bibliotekami. Sprawy biblioteczne nie były również omawiane na zakładowych egzekutywach podstawowych organizacji partyjnych (POP), a wielu ich sekretarzy nie wiedziało, kto prowadzi bibliotekę i gdzie się ona mieści ${ }^{50}$.

Na ogół biblioteki nie miały swoich lokali, jedynie placówki WDK, CKR oraz biblioteki niektórych klubów fabrycznych je posiadały. Często mieściły się w świetlicach, niekiedy na korytarzach, w biurach rad zakładowych, w niezamykanych szafach. W Żywieckiej Fabryce Śrub w Sporyszu biblioteka znajdowała się w lokalu bez okna o powierzchni czterech metrów kwadratowych; w Państwowych Zakładach Przemysłu Bawełnianego w Prudniku w jednej z hal fabrycznych, w której było $30^{\circ} \mathrm{C}^{51}$; w Zakładach Radiowych im. M. Kasprzaka w Warszawie na stołach i półkach w bibliotece przetrzymywano stroje baletowe, a w Zakładach Lamp Żarowych L2 w Pabianicach

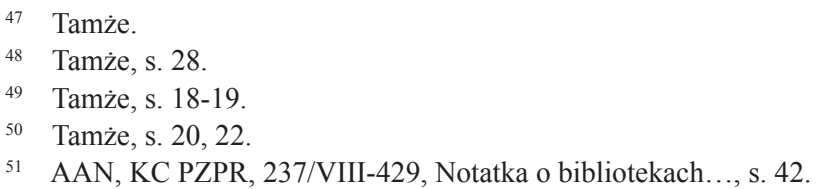


lokal biblioteczny był jednocześnie rupieciarnią. Nie zawsze pomieszczenie biblioteczne znajdowało się w dogodnym dla czytelników miejscu - biblioteka FSO mieściła się w Domu Społecznym kilometr od zakładu, podobnie biblioteka Przedsiębiorstwa Budowlanego w Szczecinku ${ }^{52}$.

Choć, jak wykazał raport z 1973 r., prawie połowa bibliotek stałych, które działały w zakładach pracy, zakładowych placówkach kulturalnych, ośrodkach wypoczynkowych czy hotelach robotniczych, nie była systematycznie uzupełniana, nie posiadała odpowiedniego lokalu i personelu, a ich księgozbiory nie przekraczały 1000 tomów ${ }^{53}$, to badania z lat 80 . pokazały, że część placówek, szczególnie przy dużych zakładach pracy, a tym samym mająca etatowych bibliotekarzy, działała bardzo dobrze, posiadała duże księgozbiory i pełniła funkcje środowiskowe (m.in. w Bielawie, Pabianicach, Kędzierzynie-Koźlu, Starachowicach czy Tarnowie ${ }^{54}$. Niektóre z nich dobrze pracowały już w latach 50., jak biblioteka w Zakładach Przemysłu Metalowego H. Cegielski w Poznaniu, która w 1957 r. posiadała kilka dużych lokali, sprzęt biblioteczny i opracowany księgozbiór liczący 14000 tomów ${ }^{55}$. Obsługiwała całe przedsiębiorstwo, trzy hotele robotnicze, ośrodek zdrowia, przyzakładową szkołę dla dorosłych - poprzez punkty biblioteczne prowadzone społecznie, oprócz tego 19 punktów funkcjonowało w halach fabrycznych; istniał też dział literatury dziecięcej dla dzieci pracowników. Jako formy pracy z czytelnikiem stosowała: wystawki książek, stałe audycje radiowęzła, recenzje książek zamieszczane w stałej rubryce na łamach zakładowej gazety, spotkania z pisarzami, dyskusje nad książkami, wieczory dla czytelników z programem rozrywkowym i konkursami czytelniczymi. Tak dobrze prowadzonych bibliotek związkowych nie było jednak wiele, co potwierdziły badania czytelnictwa robotniczego na terenie Warszawy przeprowadzone w połowie lat 50. przez Instytut Książki i Czytelnictwa Biblioteki Narodowej" Według nich robotnicy chętnie czytali, i to dużo, ale nie korzystali z bibliotek, którym zarzucali „nudę, brak literatury, która im odpowiada, a która, jeżeli już jest, to w takich ilościach, że kilometrowe kolejki zniechęcają czytających" ${ }^{57}$. Połowa przepytanych mieszkańców hoteli robotniczych wypożyczała pozabibliotecznie przede wszystkim literaturę sensacyjną, kryminalną, brukowe romanse, lekką literaturę przedwojenną, polską literaturę klasyczną

\footnotetext{
52 AAN, KC PZPR, 237/VIII-429, Analiza pracy bibliotek..., s. 11.

53 Z. Rekosz, dz. cyt., s. 21.

54 P. Bierczyński, dz. cyt., s. 129-130.

55 M. Polcyn, Praca z książką w zakładach H. Cegielskiego w Poznaniu, „Bibliotekarz” 1957, nr 7, s. 207-209.

56 M. Skwarnicki, O stała i planowa politykę nabytków w bibliotekach związów zawodowych, „Bibliotekarz” 1956, nr 1, s. 2-5.

57 Tamże, s. 3.
} 
i radzieckie książki o tematyce wojennej. Największe wyrobienie czytelnicze reprezentowali starzy technicy, majstrowie i inżynierowie, którzy korzystali z zakładowych bibliotek fachowych lub książki kupowali. Struktura tematyczna księgozbiorów związkowych wykazywała nieproporcjonalnie dużą liczbę współczesnej literatury polskiej i radzieckiej w stosunku do literatury dawnej polskiej i rosyjskiej. Założona w 1955 r. biblioteka warszawskiego Zarządu Budownictwa Mieszkaniowego 5 (Al. Niepodległości 117) otrzymała oprócz 1200 woluminów z CKR również ok. 600 książek z remanentów, loterii, niewykorzystanych nagród itp. Najczęściej były to dublety, w większości niepoczytne.

W 1955 r. podczas szóstego plenum CRZZ zajęła się pracą kulturalno-oświatową związków zawodowych, czego efektem była uchwała, która miała wskazać środki zaradcze dla zwiększenia czytelnictwa, a jednocześnie była samokrytycznym przyznaniem się do zaniedbań w stosunku do nadzorowanych bibliotek:

1. Od szeregu lat liczba czytelników w bibliotekach związkowych rośnie bardzo powoli

2. W wielu wielkich zakładach korzysta z biblioteki zaledwie 3-5 proc. załogi

3. Czytelnictwem interesują się wyłącznie sami bibliotekarze, zaś aktyw związkowy mało uwagi udziela tej sprawie

4. Bibliotekom nie zapewnia się odpowiednich pomieszczeń i funduszów

5. Księgozbiory niekiedy zaśmiecone są mało wartościową i nie czytaną lekturą i uzupełniane są bezplanowo, przy czym odczuwa się brak nowości wydawniczych, zwłaszcza z zakresu współczesnej literatury pięknej

6. Szczególnie słabo przedstawia się stan czytelnictwa w związkach zawodowych: górników, włókniarzy, spożywców, transportowców ${ }^{58}$.

Niestety, zaproponowane środki zaradcze miały charakter życzeniowy i sugerowały jedynie, co związki zawodowe powinny robić, by poprawić sytuację, na przykład „okazywać bibliotekarzom codzienną pomoc”.

Biblioteki związkowe, choć początkowo gromadziły także literaturę fachową, zachowały charakter oświatowy. Funkcjonowały poza oficjalną siecią biblioteczną, a ich działalność normowały przepisy ogólne oraz branżowe. Przepisy te były w części ignorowane przez poszczególne organy związkowe, co przekładało się na stan i działalność bibliotek, ich kadry i czytelnictwo. Ogromnym problemem, szczególnie placówek przy zakładach liczących do 500 pracowników, był brak odpowiedniego lokalu bibliotecznego, przeszkolonego personelu, odpowiednich funduszy, a także przypadkowy, najczęściej nieopracowany księgozbiór, nieprzystający do potrzeb i poziomu czytelników. Problemy sprawiało odpowiednie zabezpieczenie zbiorów,

58 Cyt. za M. Poz. [Marceli Poznański], Przeglad piśmiennictwa..., „Bibliotekarz” 1955, nr 11, s. 343, tam cyt. za „Głos Pracy” 29-30 X 1955, nr 258. 
jego opracowanie, prowadzenie prawidłowej ewidencji. Sytuację utrudniała płynność kadr i niski poziom wykształcenia ogólnego oraz przygotowania fachowego bibliotekarzy. Tylko część personelu, w dużych zakładach pracy, była zatrudniona na etatach. Pozostali pracownicy czasem otrzymywali dodatek do pensji, ale w przeważającej części pracowali społecznie. Biblioteki związkowe cechowała zróżnicowana wielkość księgozbiorów - od kilkudziesięciu do kilkunastu tysięcy woluminów, możliwości oddziaływania na otoczenie (niektóre pełniły ważną funkcję środowiskową), formy propagandy czytelnictwa. Szczególnie źle w różnego rodzaju opracowaniach, analizach i sprawozdaniach wypadały biblioteki w PGR-ach i POM-ach oraz w gminnych spółdzielniach, co w departamencie szkolenia kadr Ministerstwa PGR wywołało „poczucie potrzeby” powołania specjalnej komórki mającej zająć się sprawami bibliotek ${ }^{59}$. Podobny stosunek do spraw bibliotecznych miały poszczególne szczeble związkowe oraz partyjne.

Zachowane dokumenty wskazują, że ustalenie rzeczywistej liczby i rozmiarów poszczególnych bibliotek i punktów bibliotecznych oraz liczby czytelników przynajmniej w latach 50. XX w. jest, ze względu na niemiarodajne dane lub ich brak, praktycznie niemożliwe. Dotychczasowe opracowania dotyczące bibliotek związkowych funkcjonujących w tym okresie są fragmentaryczne, a całościowe przedstawienie ich działalności w okresie PRL może okazać się trudne i stanowi wyzwanie badawcze ze względu na rozproszone materiały archiwalne. Przy czym być może informacje w nich zawarte są tak samo wyrywkowe, jak te znajdujące się w aktach CUWPGiK, CZB czy KC PZPR z lat 50. XX w.

\section{Bibliografia}

Archiwalia:

Archiwum Akt Nowych, Centralny Urząd Wydawnictw, Przemysłu Graficznego i Księgarstwa, sygn. 65,380 .

Komitet Centralny Polskiej Zjednoczonej Partii Robotniczej, sygn. 237/VIII-13, 237/VIII-429.

Ministerstwo Kultury i Sztuki, Centralny Zarząd Bibliotek, sygn. 32, 103, 104.

Opracowania:

Bierczyński P., Biblioteki zakładowe. Stan obecny i perspektywy zmian, „Przegląd Biblioteczny" 1989, nr 2, s. 125-135.

Chumiński J., Ruch zawodowy w Polsce $w$ warunkach ksztattującego się systemu totalitarnego. 1944-1956, Wrocław 1999.

59 AAN, CUWPGiK, 65, Upowszechnianie książki rolniczej [1952 r.], klnb. 
Grabowski F., Z książką do robotników, „Bibliotekarz” 1955, nr 11, s. 337-340.

Kor. J. [Korpała J.], Przegląd piśmiennictwa. Z zagadnień bibliotekarstwa i czytelnictwa w prasie, „Bibliotekarz” 1957, nr 7, s. 211-212.

Kor. J. [Korpała J.], Przegląd piśmiennictwa. Z zagadnień bibliotekarstwa i czytelnictwa w prasie, „Bibliotekarz” 1957, nr 8, s. 246-249.

Jarosiński J., Związki zawodowe $w$ teorii i praktyce partii rządzacych w Polsce. 19441958, Kielce 2012.

Kaźmierowska K., Słobodzian M., Biblioteki związków zawodowych woj. poznańskiego w Polsce Ludowej, „Informator Bibliotekarza Wielkopolskiego” 1961, nr 1, s. 55-60.

Mikołajski M., O rozwój czytelnictwa w zakładach produkcyjnych, „Bibliotekarz” 1953, nr 5, s. 141-143.

Naumiuk J., Na początku trudnej drogi. Ruch zawodowy w Polsce Ludowej w latach 1944-1949, Łódź 1985.

Nowakówna J., Organizacja $i$ zasięg działania fachowych bibliotek zakładowych, [w:] Zagadnienia popularyzacji wiedzy i czytelnictwa, pod red. K. Wojciechowskiego, Wrocław 1966, s. 109-121.

Podgóreczny J., Szukamy nowych form zbliżenia książi do czytelnika, „Bibliotekarz” 1955, nr 11, s. 340-342.

Polcyn M., Praca z książka w zakładach H. Cegielskiego w Poznaniu, „Bibliotekarz” 1957, nr 7, s. 207- 209.

Poz. M. [Poznański M.], Przegląd piśmiennictwa. Z zagadnień bibliotekarstwa i czytelnictwa w prasie, „Bibliotekarz 1955, nr 11, s. 343-346.

Rekosz Z., Biblioteki związów zawodowych, „Bibliotekarz” 1976, nr 1-2, s. 19-30.

„Rocznik Statystyczny” 1955, druk 1956.

Rydz B., Organizacja terenowych struktur zwiazków zawodowych w południowych powiatach województwa lubelskiego w latach 1944-1975, „Radzymiński Rocznik Humanistyczny" 2012, t. 10, s. 92-101.

Skwarnicki M., O stała i planowa politykę nabytków w bibliotekach związków zawodowych, „Bibliotekarz” 1956, nr 1, s. 2-5.

Twardowski M., Biblioteka Zwiąkowa w Żyrardowie, [w:] Aktywność kulturalna włókniarzy. Praca zbiorowa, pod red. A. Kamińskiego i J. Marczaka, Łódź 1969, s. 101-116.

Zbiór przepisów prawnych dla bibliotek związkowych, wybór i oprac. Z. Rekosz, Warszawa 1977. 